Coming of Age in America 



\section{Coming of Age in America}

The Transition to Adulthood in the Twenty-First Century

EDITED BY

Mary C. Waters

Patrick J. Carr

Maria J. Kefalas

Jennifer Holdaway

甲

UNIVERSITY OF CALIFORNIA PRESS

Berkeley • Los Angeles • London 
University of California Press, one of the most distinguished university presses in the United States, enriches lives around the world by advancing scholarship in the humanities, social sciences, and natural sciences. Its activities are supported by the UC Press Foundation and by philanthropic contributions from individuals and institutions. For more information, visit www.ucpress.edu.

University of California Press Berkeley and Los Angeles, California

University of California Press, Ltd.

London, England

(C) 20 I I by The Regents of the University of California

Library of Congress Cataloging-in-Publication Data

Coming of age in America : the transition to adulthood in the twenty-first century / edited by Mary C.

Waters ... [et al.].

p. $\mathrm{cm}$.

Includes bibliographical references and index. ISBN 978-0-520-27092-3 (cloth : alk. paper) ISBN 978-0-520-27093-o (pbk. : alk. paper)

I. Adolescence-United States-History-2 Ist century.

2. Parent and teenager-United States. 3. EthnologyUnited States. 4. Social classes-United States.

I. Waters, Mary C.

HQ796.C656 20II

$305.2350973^{\prime} 0905 \mathrm{I}-\mathrm{dc2} 2$

2011009850

Manufactured in the United States of America

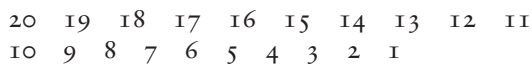

In keeping with a commitment to support environmentally responsible and sustainable printing practices, UC Press has printed this book on Rolland Enviroroo, a I00\% post-consumer fiber paper that is FSC certified, deinked, processed chlorine-free, and manufactured with renewable biogas energy. It is acid-free and EcoLogo certified. 